\title{
Left Out: How Political Ideology Affects Support for Migrants in Colombia*†
}

\author{
Alisha Holland ${ }^{\ddagger}$
}

\author{
Margaret Peters ${ }^{\S}$
}

September 7, 2022

\author{
Yang-Yang Zhou
}

\begin{abstract}
Do perceptions of migrants' politics affect their reception? The overlap between ethnicity and partisanship often makes it difficult to disentangle the role of political identity. We leverage a case in which migrants come from a similar language and religious background to isolate the role of political perceptions. We draw on a unique survey of 1,000 Colombian citizens and 1,600 Venezuelan migrants in Colombia to establish the extent of political misperceptions and their effects on migrant reception. Colombians view Venezuelan migrants as left-wing even though actual Venezuelan migrants are more right-wing than their Colombian hosts. In a conjoint experiment, we find that Colombians oppose the settlement of left-wing migrants in their communities and political views matter more than race, skill, or humanitarian need. These findings point to overlooked political tensions around migration, which may intensify as migrants gain local voting rights and politicians reinforce migrant stereotypes for electoral gain.
\end{abstract}

Keywords: migration, political misperceptions, conjoint experiment, Colombia, Venezuela

*We are grateful to colleagues at the Centro Nacional de Consultoria (CNC) for survey administration, and to Olivia Woldemikael and Daniel Rojas Lozano for excellent research assistance. We acknowledge funding support from the MacMillan Center for International and Area Studies at Yale University and the Center for Human Values at Princeton University. We thank Fiona Adamson, Hannah Alarian, Edward Gonzalez, Guy Grossman, Nicolás Idrobo, Patrick James, Efrén Pérez, and participants from the Global Research in International Political Economy (GRIPE) seminar, the UCLA CSIM Seminar, APSA 2020, USC CIS International Relations Workshop, and the University of Pennsylvania's PDRI Barriers and Bridges to Immigrants' Integration Conference for helpful comments.

†This research received institutional review board (IRB) approval from Princeton University (\#8335), UCLA (\#19-001733), and UBC (\#H19-03288). Our Pre-Analysis Plan was archived in the OSF repository https: //osf.io/download/z4apd/ (anonymized) All replication material, including $\mathrm{R}$ code and data, will be made available via Harvard University's Dataverse.

‡Associate Professor, Government Department, Harvard University, aholland@fas.harvard.edu, www.alishaholland.com

§Associate Professor, Department of Political Science, UCLA, mepeters@ucla.edu, www.maggiepeters.com

`Assistant Professor, Department of Political Science, University of British Columbia, yangyang.zhou@ubc.ca, www.yangyangzhou.com 
Do political views affect how migrants are welcomed in host countries? This question has been largely overlooked in a growing body of research on migrant reception. Migrants to wealthy democracies tend to differ in their ethnicity, language, and skill sets. To the extent differences in political views exist, they are hard to disentangle from the broader racial, religious, and labor market concerns thought to drive attitudes towards migrants. Yet the largest migrant flows occur between neighboring countries in the Global South (IOM, 2018). Migrants are often more similar to locals in their demographics, but flee governments that pursue extreme ideological projects. Left-wing governments in contemporary Venezuela, North Korea, and Cuba have produced large population outflows, as did right-wing and nationalist dictatorships in El Salvador, Eritrea, Japan, and Nazi Germany.

Little is known about how citizens in receiving countries perceive migrants' politics, or if it matters for their treatment. On the one hand, host communities may understand that migrants flee out of political opposition to their host government. While some governments with clear ideological projects, like the Soviet Union, restrict emigration, many others allow emigration and may even prefer that political opponents flee abroad (Miller and Peters, 2020). Like political exiles, many migrants that leave for economic or humanitarian reasons come to oppose the government ideology that forces them to flee (Lim, 2022). ${ }^{1}$ On the other hand, receiving communities often draw a political false equivalence and expect migrants to share the political views of their home governments. Anecdotes abound: Vietnamese refugees fled a Communist regime only to arrive to the United States to be dubbed Communists (Flood, 1977). Syrians and Iraqis fleeing ISIS were branded as terrorists (Richard, 2016). ${ }^{2}$

1 Throughout this paper, we use "migrants" to refer to a mixed flow of those leaving due to forced displacement crises and those leaving for other reasons, while recognizing that migrants is not a value-neutral term and affects the legal protections afforded to individuals.

2 For other historical examples, see the Supplementary Information (SI) Section S1. 
Political fears can be salient as host citizens worry that migrants will change the electoral dynamics or support extreme political movements in their new homes. Over fifty countries allow noncitizen residents to vote in local, regional, or even national elections (Ferris et al., 2019; Alarian, 2021). Political parties need to make calculations about how to appeal to both the existing electorate and migrants that stand to gain voting rights (Dancygier, 2017). Beyond formal rules for voter registration, residents in developing countries may worry about informal electoral practices, such as registering and buying off migrant voters before their legal incorporation.

To isolate the role of political perceptions, we examine a case where migrants share a language and religious background with their hosts but flee an opposing political context: Venezuelans in Colombia. Venezuelans have migrated in large numbers as unemployment and food shortages mounted under left-wing populist governments. During the period of study, Colombia was governed by center-right democratic governments. Colombia allows Venezuelans to vote in local elections after five years of residence, making their electoral participation a looming issue. We fielded a face-to-face survey with 1,000 Colombians and 1,600 Venezuelan migrants in Colombia before local elections in 2019. The survey is unique in that it includes both Colombians and Venezuelans living in Colombia, allowing us to compare host communities' perceptions to the actual views of migrants.

We find substantial and consequential political misperceptions. First, a large gap exists between Colombians' political perceptions and Venezuelans' self-reports. For instance, while $40 \%$ of Colombians believe the majority of Venezuelan migrants identify with the political left, only $12.1 \%$ of them - even less than Colombians - actually do. Second, political misperceptions could mask underlying racial or economic animus. We therefore test if political views motivate migrant exclusion using a conjoint experiment that minimizes social desirability bias and allows 
us to compare the relative importance of migrant attributes. We find that Colombians strongly disfavor migrants from the political left, and ideology is more important than race or skill in shaping which migrants Colombians prefer to host. These findings differ, then, from the substantial research on attitudes towards immigrants in wealthy democracies that emphasizes racial and labor market anxieties.

While we cannot isolate the origins of political misperceptions, we rule out that direct contact and strategic calculations drive misperceptions. We conducted our survey in two cities, Cali and Cúcuta, that differ in their local demographics. Cúcuta is a relatively small city on the border, where Venezuelans have long interacted with Colombians. Venezuelans now make up a quarter of the population in some districts and could swing local electoral outcomes. Cali is a large city on the opposite side of Colombia, where Venezuelans are a new addition to the city and constitute less than $1 \%$ of the population. Their electoral participation is unlikely to change local voting outcomes. If misperceptions stem from limited exposure to migrants, we should find that individuals with Venezuelan friends or living in Cúcuta with more daily contact with Venezuelans should predict more accurate views. Instead, we find few differences in political misperceptions based on social networks or city of residence. If political misperceptions are adopted or matter most when migrant electoral incorporation will swing political outcomes, then individuals who are strong partisans, misperceive ideology, and live in migrant enclaves should be most likely to care about their political views. But, while right-wing respondents are more strongly opposed to the reception of left-wing migrants, we find no differences in concern about the political ideology of migrants based on whether individuals misperceive their ability to vote or by their city of residence.

Instead, we suggest that national political elites cultivate political misperceptions for their 
electoral advantage. We analyze Twitter data to illustrate how right-wing politicians have fostered political misperceptions to discredit more moderate left-wing opponents. Colombian politicians stoke fears that Venezuelan migrants sympathize with left-wing views, import "socialist" ideas, and vote in elections. Elite cues are consistent with the fact that political misperceptions exist and matter across cities with different levels of contact and electoral demographics. In so doing, our paper builds on work on how political entrepreneurs can heighten the salience of some identities over others. While most research focuses on the instrumental creation of ethnic identity (e.g. Posner, 2005; Pérez, 2015), we emphasize how politicians can successfully use political differences - not just racial or linguistic ones - to mobilize anti-immigrant sentiment and build electoral support.

Taken together, our findings highlight the role that political misperceptions can play in how migrants are received in host countries. Political fears can be a critical, and overlooked, driver of hostility towards migrants. We show that ordinary Colombians care about migrants' views, even when compared to more concrete differences like race and skill. Conversely, scholars might overstate the role of ethnic prejudice when it aligns with other political cleavages. We also provide unique evidence that perceptions of migrants' political ideologies are often wrong. Politicians and partisan media in receiving countries have incentives to cultivate political misperceptions as a way to discredit political opponents in their countries. In many countries still shaped by Cold War divides, the fear of left-wing groups coming to power remains a salient fear. Right-wing politicians have incentives to play up these fears and associate them with migrant communities to mobilize turnout and strengthen their support. One implication is that the anticipated electoral consequences of immigration may diverge from those in reality. Despite Colombians' fears that new migrants will push politics to the left, Venezuelans living in Colom- 
bia are even more right-wing than Colombians. Similarly, although the Republican Party in the US laments "undocumented Democrats," many Latino migrants hold conservative social views and anti-Communist views in line with the party. The political incorporation of migrants fleeing left-wing governments can strengthen the very right-wing parties that decry migrant presence.

\section{Theory: How Political Identity Shapes Migrant Reception}

Political concerns are largely absent in the literature exploring public attitudes toward immigration. The underlying assumption is that political identities are less salient than employment, fiscal, or cultural strains from migration. ${ }^{3}$ Yet, many migrants flee extreme ideological projects. The high stakes of political situations that lead to mass emigration can raise concerns in receiving countries about migrants' political loyalties. About a third of countries extend the right to vote - particularly in local elections - to resident non-citizens (Ferris et al., 2019; Alarian, 2021), and many migrants can eventually become citizens and vote. In these contexts, political parties court the votes of migrants (Dancygier, 2017), and the broader public may worry about how migrants' will change electoral outcomes.

Electoral inclusion would have few consequences if migrants hold political views in line with the distribution of the host population. But since receiving communities cannot observe the political ideology of every migrant, they need to use heuristics to judge their politics. A common assumption is that migrants share the ideological views of their home government. Indeed, Simpser (2020) shows that political norms, such as attitudes towards corruption, can be transmitted by immigrants and persist across generations. Media portrayals often reinforce this view: for instance, Syrians are stereotyped as terrorists and ISIL supporters, even though

$3 \quad$ For a review, see Hainmueller and Hopkins (2014); cf. Whitaker and Giersch (2021). 
they fled the violence perpetrated by these groups (Rettberga and Gajjalab, 2015). During the Cold War, the Thai media portrayed Vietnamese refugees as a potential "vanguard" for Communism, even as migrants fled and disavowed their government (Flood, 1977). In much of Latin America, Venezuelans are stereotyped as socialists, or "Castro-Chavistas." Given the ease and availability of such stereotypes, our expectation is that most host communities create a political false equivalence between migrants and the ideology of their home country. H1a. Host communities perceive the dominant ideology of migrants to align with the government that they left.

An alternative heuristic is to assume that migrants reject the ideology of the government that they flee. Cubans in Miami, for instance, are loyal Republicans precisely because they experienced Communism and have no desire to see anything like it spread in the US. Forced migrants may be understood as "voting with their feet" to leave regimes with which they disagree. Indeed, Lim (2022) show that emigrants differ in their political preferences from those that remain in their home country; they tend to hold more progressive views and voice political opposition to the regime in power. Host communities may think of migrants as similar to political exiles, who leave due to opposition to their home governments. To the extent migrants export politics, it should be opposition to the dominant ideology in their home country. But we expect that misperceptions linking migrants' views to those their home country governments will likely prevail. Our expectation is that H1. Host communities perceive the dominant ideology of migrants to align with the government that they left, even though most migrants oppose their home regime. We explore the origins of political misperceptions and heterogeneity in host communities in the mechanisms section.

Even if political misperceptions exist, it's unclear whether they play an important role in 
shaping migrant reception. Classic explanations of attitudes towards migration emphasize economic factors (e.g., Mayda, 2006; Hainmueller and Hopkins, 2015; Goldstein and Peters, 2014). Political perceptions may play a minor role compared to issues like labor market competition, fiscal strain, or the broader (sociotropic) effects on the national economy that affect individuals' everyday lives. In developing countries, migrants often have similar skill sets to host populations, which intensifies labor market competition (e.g. Adida, 2014; Gaikwad and Nellis, 2017). Developing countries also have smaller and lower-quality welfare states, so migration can strain public services that are already insufficient (Hanson, Scheve and Slaughter, 2007). The implication is that host communities should be most concerned about the skills, welfare dependence, or overall economic effects of migration, rather than any electoral consequences.

Additioanlly, misperceptions can be a guise for racial or ethnic animus, which has been shown to drive host community animosity in a wide range of settings (e.g., Thachil, 2017; Bhavnani and Lacina, 2018; Cogley, Doces and Whitaker, 2018). People may report political misperceptions to rationalize their anti-immigrant attitudes, particularly if racist views are less socially acceptable. (Hopkins, Sides and Citrin, 2019), for instance, find that Americans' misperceptions of group size are used to rationalize people's policy preferences for less immigration. However, if political misperceptions are a consequence of out-group animosity, then political leanings should play a minor role when using empirical techniques to account for social desirability bias and give voice to broader cultural anxieties.

Concerns about political views may seem to presume well-structured, programmatic politics that do not exist in many developing democracies. Yet politicians may try to draw "us" versus "them" distinctions around political groups from foreign countries when partisanship is weak and poorly defined at home. In particular, the boogeyman of socialism casts a powerful shadow 
in many developing countries and particularly where neighboring countries experiment with left-wing projects. Host communities also may care about migrants' political impacts because they perceive them as vulnerable to recruitment into armed or criminal groups. Migrants often flee crime and security threats (Hiskey et al., 2018), which may raise concerns about importing crime to host countries or acting as "fifth columns," people within a country who supposedly collaborate with hostile foreign powers to subvert domestic politics (Radnitz and Mylonas, 2022).

Due to the efforts of political entrepreneurs and nearby extreme political projects, ordinary citizens may come to see the potential political impacts of migration as important threats. We therefore expect that H2. Host communities care more about the political ideological profile of migrants compared to their skill, race, or likely welfare burden.

\section{Context: The Politicization of Venezuelan Migration}

Venezuelans and Colombians share many demographic similarities. Citizens speak the same language (Spanish), identify with the same dominant religion (Catholicism), and have mixed skin tones. ${ }^{4}$ But the countries have followed divergent political trajectories. Colombia elected presidents from the political right during the period of study, while Venezuela was governed by left-wing populist leaders.

Colombia has endured more than 50 years of civil conflict, involving left-wing guerrillas groups, right-wing paramilitaries, and the state. The conflict killed 220,000 people and displaced an estimated 10\% of Colombia's population (Steele, 2017). Due to fears of left-wing violence, the majority of Colombians identify with the political right and the country didn't follow Latin America's "left turn" in the 2000s. In 2022, Gustavo Petro, a former guerrilla, managed to

$4 \quad$ These demographic similarities apply to many Latin American countries (minus Brazil) that have received Venezuelan migrants, such as Ecuador, Peru, and Chile. 
overcome fears of the left and harness popular frustration with the existing political class to win the presidency. Colombia's neighbor, Venezuela, has elected left-wing populist presidents since 1999. President Hugo Chávez embarked on a project of what he dubbed "21st century socialism." While Chávez enjoyed broad popular support, an economic crisis and increased repression diminished support for his successor, Nicolás Maduro. Venezuela's GDP shrunk by $62 \%$ since Maduro took office in 2013, constituting one of the largest economic collapses outside of war.

Venezuela's economic and political turmoil has forced broad segments of the population to leave. ${ }^{5}$ While early migrants from Venezuela tended to be political or economic elites, recent migrants have come from diverse economic backgrounds - many are poor, less educated, and made the trip on foot - and less politically involved than those who left earlier.

Colombia has received the largest number of migrants from Venezuela and largely has welcomed them. As of 2019 (when our survey was fielded), 1.8 million Venezuelans had fled to Colombia. In 2017, the Colombian government created special residency permits (Permiso Especial de Permanencia, PEP) that granted Venezuelans two years of legal residency, as well as the right to right to work, education, and public health care. ${ }^{6}$ The government expanded the program to regularize all Venezuelans who had entered in $2021 .^{7}$

Foreigners can vote in local elections in Colombia after five years of residency. ${ }^{8}$ Colombia is similar to most Latin American countries in this respect: ten Latin American countries $5 \quad$ While some of these migrants do not meet the definition under the 1951 Refugee convention, they are covered under the Cartegena Declaration.

6 For an overview of Colombia's response, see "Todo lo que tiene que saber sobre la migracion venezolana," Ministerio de Relaciones Exteriores, November 1, 2018, www.migracioncolombia.gov.co/infografias/todo-lo-que-tiene-que-sabersobre-la-migracion-venezolana

7 "Duque presenta proyecto para regularizar a los migrantes venezolanos, de qué trata?," El Espectador, February 8, 2021.

$8 \quad$ Law 1070 of 2006. 
enfranchise non-citizen populations, and most provide clear paths to citizenship with full voting rights (Escobar, 2017). Given that the increase in Venezuelan migration began in 2015, most Venezuelans could not vote in the 2018 presidential and 2019 mayoral elections that are the focus here.

Colombia differs from many advanced industrial economies in that right-wing politicians led the welcoming response to migrants. A center-right president, Juan Manuel Santos (2010-18), spearheaded the initial tolerant response to Venezuelans. Santos drew on a long history of Venezuela receiving migrants from Colombia's civil war. While most Colombians were internally displaced, some Colombians fled into Venezuela and others lived fluid cross-borders lives (Janetsky, 2019). Subsequently, President Iván Duque (2018-22), who also came from the political Right, regularized the status of Venezuelan migrants and emphasized the shared history and solidarity between the neighboring countries. ${ }^{9}$ While justified by a shared history of migration, the lack of a xenophobic response to migrants is not unique to the Colombian Right - Brazil, Chile, and Peru all welcomed Venezuelans under right-wing administrations.

The Colombian government has attempted to prevent the politicization of migration at the local level. Prior to the 2019 local elections that form the backdrop for our survey, the Attorney's General Office led a campaign (along with the IOM and USAID) called “There's space for all" to encourage tolerance towards Venezuelan migrants. The main political parties made a pact not to campaign on anti-migrant platforms. ${ }^{10}$ With some important exceptions, local campaigns involved little explicit discussion of migration issues. ${ }^{11}$ Candidates discussed

$9 \quad$ "Duque presenta proyecto para regularizar a los migrantes venezolanos, de qué trata?," El Espectador, February 8, 2021.

10 "Partidos colombianos firman pacto político contra la xenofobia," Semana, 22 March 2019, migravenezuela.com/web/articulo/pacto-politico-contra-la-xenofobia-enelecciones-2019-1015.

11 "En silencio sobre la migración en la campaña es pura estrategia," Silla Vacia, 9 October 
migration primarily in terms of its effects on local employment and services. ${ }^{12}$

Although right-leaning governments have welcomed migrants and tried to prevent xenophobic scapegoating, not all politicians have followed suit. Some right-wing politicians, such as former president Álvaro Uribe, have cultivated fears of left-wing Venezuelan migrants in attempts to scare voters away from the political left. We return to these maneuvers in the mechanism section. More broadly, some evidence suggests that the political Right or independents have benefitted from increased migration. Rozo and Vargas (2021) show that Colombian voters in municipalities that received more Venezuelan migrants were more likely to turnout and elect right-wing candidates. Woldemikael (2022) finds that increased migration resulted in the entrance and victory of more independent candidates. Yet such studies of electoral impacts can't distinguish whether migrant-receiving communities are concerned about the political, fiscal, or cultural impacts of migration.

\section{Data and Research Design}

We now describe our unique survey and empirical strategy to distinguish the role of political identities from other racial and fiscal anxieties in shaping the reception of migrants.

\section{Case Selection and Survey Sampling}

In August-October 2019, we conducted a face-to-face survey of Colombians and Venezuelan migrants in Colombia. We timed our survey to coincide with the run-up to local and regional 2019, lasillavacia.com/silla-santandereana/silencio-sobre-migracion-campanapura-estrategia-73866.

12 For instance, each candidate registers an official campaign platform. The majority of platforms in Cúcuta mentioned efforts to create labor opportunities in part to absorb migrants, reduce insecurity, and improve migrant treatment. All platforms are available at www . cucuta-nortedesantander .gov . co/noticias/programas-degobierno-candidatos-a-alcaldia-de-cucuta-222916 
elections in October 2019. Given that political fears generally are not identified as important, we were interested in the most-likely time period in which they would matter.

We conducted the survey in two Colombian cities, Cúcuta and Cali, to vary the concentration of migrants and improve the survey quality. Cúcuta is located on the Venezuelan border and has absorbed the largest fraction of Venezuelan migrants. Registered migrants constitute $6.34 \%$ of the city population and the number of unregistered Venezuelans likely is far larger. In some districts within the city, a quarter of the population are regularized migrants from Venezuela (DANE 2018). Residents in Cúcuta have a long history of interacting with Venezuelans as populations on both sides flow across the border for work and services. In contrast, Cali is Colombia's third-largest city, with smaller concentrations of Venezuelans (less than 1\% of the city population) and little history of interaction. Cali instead has received substantial internally displaced people (IDPs) due to its proximity to rural areas with active conflict. Additionally, Cali has a large Black population (roughly 20 to 25\%, according to the 2015 census) compared to less than $3 \%$ identifying as Black in Cúcuta. This paired comparison allows us to examine whether differences in contact and electoral demographics drive political misperceptions and fears. In addition, Venezuelans in Cúcuta and Cali are spatially concentrated, making them easier to survey without a standard sampling frame compared to larger cities (like Bogotá and Medellín) with diffuse Venezuelan migrant populations. We focus on urban populations, given that almost all Venezuelan migrants have settled in large cities with greater labor market opportunities, and we would not have been able to reach sufficiently large rural samples.

In each city, we surveyed about 800 Venezuelans and 500 Colombians. We excluded ColombianVenezuelan dual citizens from our sample, given that they likely have different access to services 
and views on migration. ${ }^{13}$ The demographics of Colombians and Venezuelans are similar to available surveys and administrative data on the city populations (see SI Section S2). Most Colombians in our sample had at least some indirect contact with Venezuelans and $60.2 \%$ said they had at least one Venezuelan friend.

The only differences to note are that the Colombian sample $(\mathrm{N}=1,005)$ included slightly fewer men than women (55.4\%), and mainly Mestizo (51.5\%) and white (29.4\%) respondents, with about $11.1 \%$ identifying as Afro-descendent and $3.3 \%$ as indigenous. Consistent with the city demographics, Colombian respondents were largely low-income and unskilled, with only primary or secondary education, and the majority working in the informal economy. Compared to nationally representative samples from the LAPOP Colombia survey (2018), SI Section S3 shows that our Colombian respondents tended to identify slightly more with the political left (although most still lean right) and were wealthier - reflecting that our respondents are drawn from urban areas.

By comparison, the Venezuelan migrant respondents $(\mathrm{N}=1,612)$ were younger and more educated than the Colombians on average (77.3\% have at least a secondary education). Despite higher levels of education, the vast majority worked in the informal economy in Colombia (91.6\%). Most said that they left Venezuela for economic reasons (82.9\%). Compared to the last available LAPOP survey on Venezuela (2016-2017), our Venezuelan respondents in Colombia are younger and more likely to be looking for work and having trouble making ends meet.

13 Sample sizes were determined by power calculations and our available funding. The margin of error for the survey of Colombians in both cities is about $4.5 \%$ and $3.4 \%$ for Venezuelans. In the conjoint experiment, we are able to find minimum effect size of 0.1 with a $95 \%$ confidence interval. 


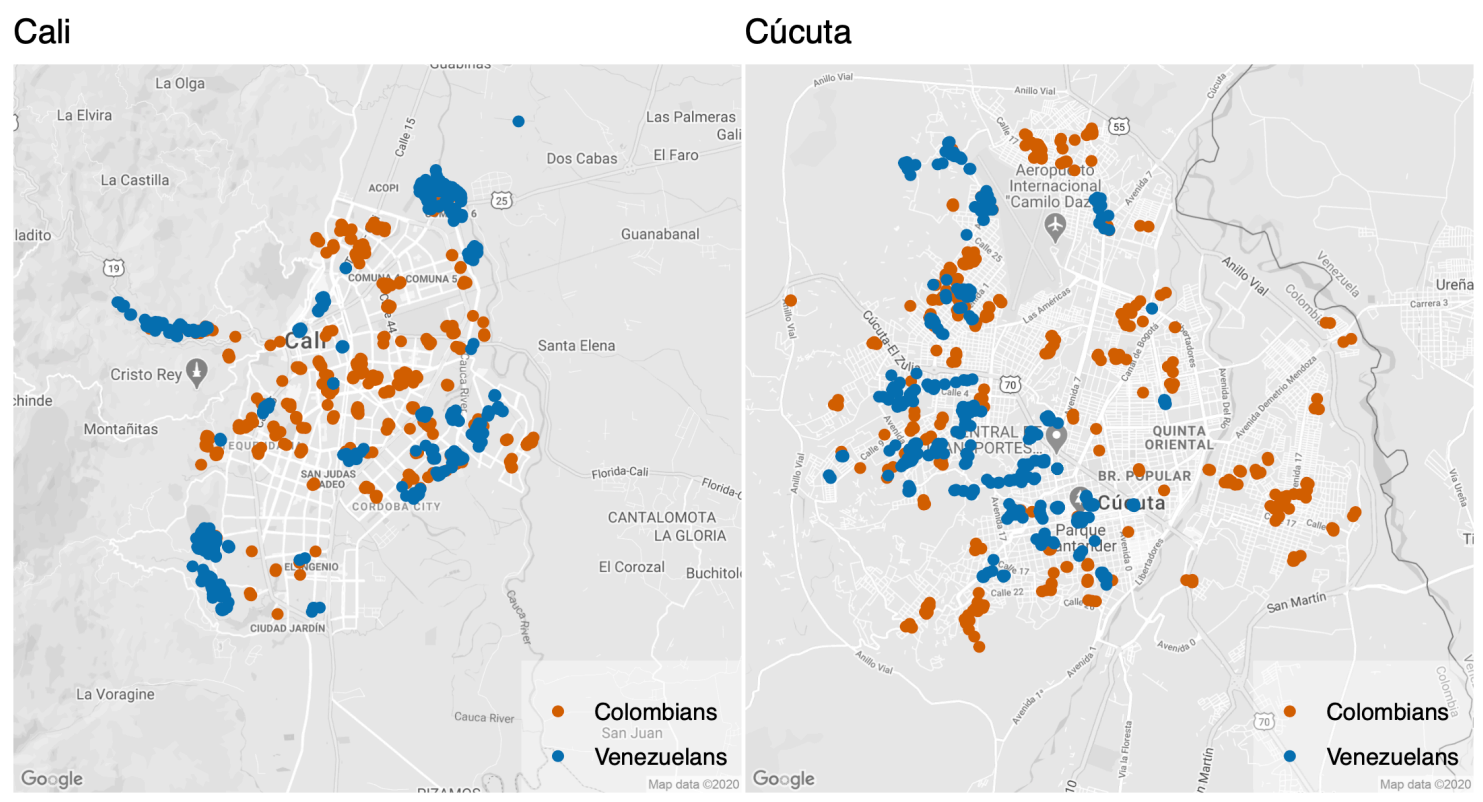

Figure 1: Maps of Cali (right) in southwest Colombia, and Cúcuta (left) in northern Colombia along the Venezuelan border, showing the locations of survey respondents. Google basemap.

\section{Survey Implementation \& Research Ethics}

We ran a face-to-face survey with a respected Colombian survey firm. ${ }^{14}$ Respondents received roughly $\$ 5$ USD in compensation to complete the survey, which is equal to about 3 hours at minimum wage. This amount was chosen to compensate people for their time without inducing participation. The survey for Venezuelans lasted approximately one hour; the survey for Colombians lasted 45 minutes. All enumerators were Colombians from the city of the survey. ${ }^{15}$

14 The surveys were approved under IRB protocols XXX at XXX University, YYY at YYY University, and ZZZ at ZZZ University (redacted for anonymity). Respondents were told that the survey was sent by researchers at XYZ (redacted for anonymity) universities. Prior to conducting the survey, we submitted a pre-analysis plan with our sampling plan, hypotheses and related survey questions, and empirical strategy. Centro Nacional de Consultoría (CNC) ran the survey.

15 Contact information was collected for quality control purposes. All data were kept on a secure server to ensure confidentiality. More than $10 \%$ of surveyed individuals were recontacted in each city to check enumerators' work. The survey was programmed into the Qualtrics offline software application. 
For Colombian respondents, we conducted a household survey. The survey firm designed a stratified sample according to socioeconomic blocks. Enumerators were assigned a random start location on each block and used a skip rule to select houses. For Venezuelans, we used two strategies to create a high-quality sample due to the lack of an existing sampling frame. First, we conducted a household survey in neighborhoods that official registries identify as having high concentrations of Venezuelans. Enumerators randomly selected blocks as starting points and then used a skip rule between units. However, migrants living in fixed households may be wealthier or live in enclaves with less direct contact with Colombians. As a second strategy, we created a list of places where Venezuelan gather (government offices, spot employment markets, shelters, churches) and randomly selected gathering points. Enumerators then interviewed migrants they met at these points according to a skip rule, finding space to conduct the survey in private. We screened for Venezuelans who had moved in the last three years to create a comparable group of migrants. Figure 1 shows the locations of our surveys. The Colombian samples are geographically spread across these two cities. The Venezuelans, however, cluster together in enclaves, similar to migrant populations throughout the world.

Our survey, discussed in more detail below, focused on opinions about politics and migration. We framed sensitive questions, such as those on recruitment by gangs or irregular groups, in terms of the experiences of individuals or their family members to improve reporting and avoid recounting personally traumatic experiences. During the informed consent process, enumerators also ensured that respondents understood that their participation was voluntary, that they could terminate the survey at any time, and that they did not have to answer every question. We randomized the order of the observational questions, as well as a conjoint experiment, to minimize order effects. 


\section{Empirical Strategy and Hypotheses}

We use a combination of descriptive and experimental evidence to test the extent and role of political misperceptions in attitudes towards migrants. First, we examine the extent and nature of political misperceptions. We leverage our unique survey that included both Colombians and Venezuelan migrants living in Colombia. This design allows us to compare perceived and actual views. For our first hypothesis, we expect that Colombian respondents have widespread political misperceptions of Venezuelan migrants. More specifically, we expect that Colombians believe that Venezuelans identify with the political left, while most Venezuelans disavow the left; Venezuelans are able to vote in local and national elections, while almost no Venezuelans have gained the right to vote; Venezuelans receive vote-buying offers, while most Venezuelans have not received them; and Venezuelans are vulnerable to recruitment by left-wing guerrillas and gangs, while few Venezuelans report recruitment attempts.Given that survey respondents are notoriously bad at judging percentages, we asked Colombian respondents whether they thought the majority of Venezuelan migrants had a given set of political views or experiences. We asked Venezuelans directly whether they (or in the case of sensitive questions, a family member) held a given view.

Second, following common practice to understand the importance of different factors, we included a forced choice conjoint experiment in the surveys to Colombians and Venezuelans. Respondents evaluated different profiles of migrants. We asked which migrant they would prefer to have stay in their city and receive housing and employment assistance. A conjoint experiment allows us to compare political views to other factors theorized to influence migrant preferences, like race, skills, and welfare dependence. In the conjoint experiment, we vary the political leanings of the migrant, rather than relying on respondents' stereotypes. If political 
misperceptions are adopted to mask other anxieties, then factors like race and skill should play a larger role in the conjoint experiment. Each respondent saw five pairs of migrant profiles that randomized the following attributes:

- Political ideology: left, center, or right

- Origin: IDP from Valle del Cauca, IDP from Norte de Santander, or Venezuelan

- Skill level: low, medium, or high

- Employment prospects: very likely to get work, unlikely to get work, cannot work

- Reason for leaving: Fear of arrest by the government, violence by guerrillas/irregular forces/paramilitaries, fear of crime in their area, or poverty

- Race: Mestizo or Black

- Gender: Male or Female

If our theory holds, then the political views of migrants should be a stronger predictor of willingness to host them than more common factors like race or skill. In particular, we expect that Colombians should be less likely to welcome migrants with left-wing political views. To test this, we first calculate the Average Marginal Component Effects (AMCEs) following Hainmueller, Hopkins and Yamamoto (2014). An AMCE represents the increase in the probability that a profile will be chosen if the component value is changed from one level to the other, averaged over all the other profile attributes. We also look at the importance of economic, skill, and racial factors in shaping reception attitudes. The design allows us to examine if political perceptions are consequential, or simply mask underlying racial or economic anxieties about migration. Conjoint experiments minimize social desirability bias because respondents don’t need to justify their choice of migrant profiles. If alternative factors outweigh political ideology, we should see common factors identified in the literature, such as the skill level of Venezuelans or race weighed more heavily when considering different migrant profiles. In particular, we test whether Colombians oppose Venezuelans with similar skills who can displace them in the labor market (labor market); oppose Venezuelans likely to use social welfare programs (fiscal burden); 
prefer those with more skills (sociotropism); oppose Black migrants (racism); or support those fleeing danger and female migrants (humanitarianism).

While we cannot directly test the origins of political misperceptions, we examine plausible channels rooted in direct experience, strategic adoption, or elite messages. First, we asked Colombian respondents how many Venezuelan friends or work colleagues they have. If contact dispels misperceptions, then we expect that individuals with more close contacts or who live in cities with more experience with Venezuelans, such as Cúcuta, should have more accurate views of Venezuelans. Second, we examine the extent to which misperceptions are electorally self-serving. If misperceptions are adopted for strategic partisan advantage, we expect that individuals may be more likely to cast migrants as holding opposing political views and disfavor migrants who hold opposing political views. Individuals who believe that Venezuelans can vote in elections and who live in cities with high electoral concentrations also should care more about migrants' political ideology. We estimate conditional conjoint effects based on a respondent's ideology, belief about whether Venezuelans can vote, and city of residence. Finally, we examine the role of political elites through a qualitative analysis of media and Twitter messages in the run-up to elections. We look for evidence that right-wing politicians cultivate generalized fears about the electoral participation of Venezuelans.

\section{Main Results}

We begin with a description of the mismatch in Colombians' perceptions of Venezuelans' political views and then consider the relative importance of political views in migrant reception. 


\begin{tabular}{|l|l|l|}
\hline & $\begin{array}{l}\text { \% of Colombians who } \\
\text { believe that the } \\
\text { majority of Venezuelan } \\
\text { migrants }\end{array}$ & \% of Venezuelan migrants \\
\hline Support the left & $40 \%( \pm 2.4)$ & $12.1 \%( \pm 1.2)$ \\
\hline Support Maduro & $23.6 \%( \pm 1.9)$ & $0.1 \%( \pm 0.1)$ \\
\hline $\begin{array}{l}\text { Can vote in national } \\
\text { elections }\end{array}$ & $37.4 \%( \pm 2.2)$ & $0 \%$ \\
\hline $\begin{array}{l}\text { Can vote in local } \\
\text { elections }\end{array}$ & $29.5 \%( \pm 2.1)$ & $1.4 \%( \pm 0.4)$ \\
\hline $\begin{array}{l}\text { Received a } \\
\text { vote-buying offer from } \\
\text { Colombian politicians }\end{array}$ & $55.5 \%( \pm 3.4)$ & $3.7 \%( \pm 0.7)$ \\
\hline $\begin{array}{l}\text { Support guerrilla } \\
\text { groups }\end{array}$ & $46.1 \%( \pm 2.4)$ & $\begin{array}{l}\text { We did not ask this question directly, } \\
\text { but } 0.7 \%( \pm 0.3) \text { had a family member } \\
\text { approached by a guerrilla group for } \\
\text { recruitment }\end{array}$ \\
\hline $\begin{array}{l}\text { Have criminal ties to } \\
\text { gangs }\end{array}$ & $78.5 \%( \pm 1.8)$ & $\begin{array}{l}\text { We did not ask this question directly, } \\
\text { but } 0.5 \%( \pm 0.3) \text { had a family member } \\
\text { approached by a gang for recruitment }\end{array}$ \\
\hline
\end{tabular}

Table 1: The Prevalence of Political Misperceptions: Comparing Colombians' Beliefs with Venezuelans' Reported Experiences. Margins of error in parentheses.

\section{The Extent of Political Misperceptions}

Our unique survey allows us to compare Colombians' perceptions to Venezuelan migrants' actual preferences and experiences. Consistent with our first hypothesis, Colombians have substantial misperceptions about Venezuelans' political views and behavior: $40 \%$ of Colombians think that most Venezuelan migrants support the political left. Additionally, $29.5 \%$ believe that most Venezuelans already have the right to vote in local elections (even though only $1.4 \%$ have met the five-year residency requirement), and $37.4 \%$ believe that migrants have the right to vote in national elections, which is reserved for citizens.

In contrast, we find that only $12.1 \%$ of Venezuelans placed their political views on the left. This is comparable to the share of Colombians, $11 \%$ in our sample. If anything, Colombians are more likely to be centrist, compared to Venezuelans, who are more likely to position themselves 
on the far right. It is possible that the limited identification of Venezuelans with the political left reflects social desirability bias. Venezuelan respondents may want to disavow media misperceptions, even if they truly support the left. Additionally, a general problem in measuring political identification is non-response: $12 \%$ of Venezuelan migrants did not answer the question about political identification. However, $52.7 \%$ of Venezuelans admitted that they voted for President Hugo Chávez in the past and $44.8 \%$ evaluated his presidency as "good" or "very good" on a 5-point scale. This suggests that Venezuelans were willing to admit to once supporting left-wing politicians. Crucially, many no longer identify with the left and have distanced themselves from the Maduro government. While $24.8 \%$ had voted for Maduro, only two respondents $(0.1 \%)$ said that they wanted Maduro to continue as president and $97.2 \%$ viewed his presidency as "bad" or "very bad" on a 5-point scale. A more general turn away from the left seems apparent: when asked how they would vote if given the right to in 2018 Colombian presidential elections, $43.9 \%$ of Venezuelans said that they would support Duque, which far exceeds the fraction supporting Petro $(3.5 \%) .{ }^{16}$

Colombians additionally saw Venezuelans as susceptible to vote buying and armed recruitment. More than half $(55.5 \%)$ of Colombians believe that politicians try to buy Venezuelans' votes. ${ }^{17}$ However, only $3.7 \%$ of Venezuelan migrants in our sample said that they received an offer to sell their vote. Again, there may be concerns of underreporting due to social desirability bias. Yet $28.7 \%$ said that they had received a vote buying offer during the last election when they lived in Venezuela. Colombians are also concerned that Venezuelans may perpetuate Colombia's internal conflict: $46.1 \%$ of Colombians believe that the majority of Venezuelan migrants support left-wing guerrilla groups, $72.9 \%$ are worried that Venezuelans will be recruited 16 The rest did not know the candidates or whom to support.

17 This question on vote buying was only asked to half the sample. 
into a guerrilla organization, and $78.5 \%$ worry that Venezuelans will join a criminal gang (which often can be a source of money). In contrast, a small minority of Venezuelans said that they or a family member were approached to join a guerrilla group (0.7\%) or a gang (0.5\%). Supporting H1, political misperceptions by Colombians about Venezuelan migrants therefore seem widespread.

Yet the descriptive evidence alone makes it hard to disentangle the importance of political misperceptions in shaping the reception of Venezuelans. Colombians voice a variety of fears about Venezuelan migration. More than half $(57.6 \%)$ say that they are competing with Venezuelans for work and $78 \%$ think that it has become harder to obtain public services. Unlike poorer developing countries with large migrant flows, Colombia is a net fiscal contributor to hosting Venezuelan migrants and Colombians feel the strain: $62.9 \%$ believe that the international community is not providing enough aid and $80.1 \%$ think their own taxes will likely go up because of the migrants. Despite cultural similarities, Colombians also have concerns about their societal impact: only $38.9 \%$ say that Venezuelans have integrated successfully. We now turn to the conjoint experiment to understand the role of political anxieties as compared to other common racial, labor market, and fiscal concerns in migrant reception.

\section{The Relative Importance of Political Views}

Our second hypothesis states that political concerns shape migrant reception more than concerns over economic competition or race. Figure 2 shows that the political ideology of the hypothetical migrant is a major determinant in their reception, more so than other attributes. Among Colombians, respondents preferred migrants who sympathized with the political center

or the right: the AMCE for supporting the center was $0.09(95 \% \mathrm{CI}=[0.06,0.1])$ and for the 


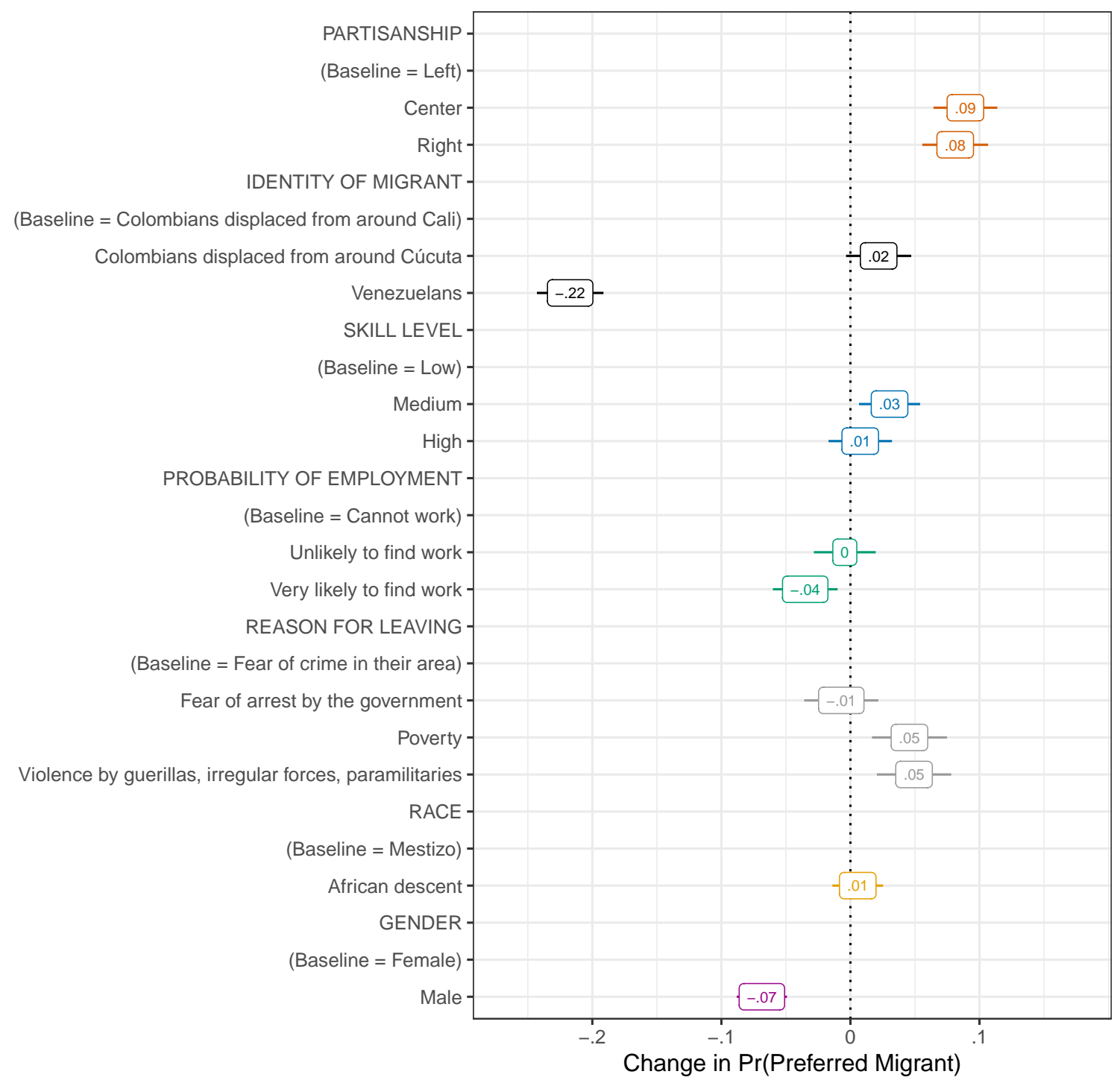

Figure 2: Conjoint estimates with 95\% CIs for Colombian respondents asked to choose their preferred migrant profile in a pairwise comparison.

right was $0.08(95 \% \mathrm{CI}=[0.06,0.1])$. The main penalty comes from holding leftist views; center and right-wing migrants gain similar levels of support. Answering this same conjoint exercise, shown in SI Figure S5, Venezuelan respondents were also more supportive of migrants who sympathize with the center at $0.03(95 \% \mathrm{CI}=[0.01,0.05])$ or right at $0.03(95 \% \mathrm{CI}=[0.007$, 0.04]). This preference further reinforces how inaccurate Colombians' stereotypes of Venezuelans are in reality: most Venezuelan migrants don't want those who sympathize with the political 
left either.

This figure also provides little support for theories focused on alternative theories based on labor market or racial anxieties. Unlike similar conjoint experiments run in the US (Hainmueller and Hopkins, 2015) or Europe (Bansak, Hainmueller and Hangartner, 2016), skill has a very small or null effect on support for hypothetical migrant profiles. ${ }^{18}$ Colombians actually have a slight preference for migrants who cannot work, in contrast to the fiscal burden hypothesis. One reason for the limited impact of economic factors is that humanitarian concerns, especially about those from one's own national group, may increase tolerance of migrants in developing country settings. Among Colombians, hypothetical migrants who could not take care of their families or who were fleeing guerrilla or paramilitary violence received more support than those fleeing common crime or threat of arrest by the government. Women also are preferred over men, which could reflect the role of humanitarian concerns in shaping attitudes (see SI Section S5 for additional analyses).

We also find little support for racial determinants of attitudes. If political misperceptions simply masked racial animus, we would have expected race to drive the selection of migrant profiles in the conjoint context in which respondents don't specify why they choose a given migrant. But race plays little role in profile selection. The only other attribute with a large effect is the respondent's origin. We see strong regional and national preferences: respondents favor their co-nationals and co-regionals - a "sons of the soil" effect (Bhavnani and Lacina, 2018). We now turn to the heterogeneous effects that help shed light on why Colombians hold misperceptions and use political cues to evaluate migrants.

18 It is possible that the question may have been easier to understand if framed in terms of concrete occupational categories. However, skill did matter somewhat to Venezuelan respondents, suggesting that the question operated as expected. 


\section{Where do misperceptions come from?}
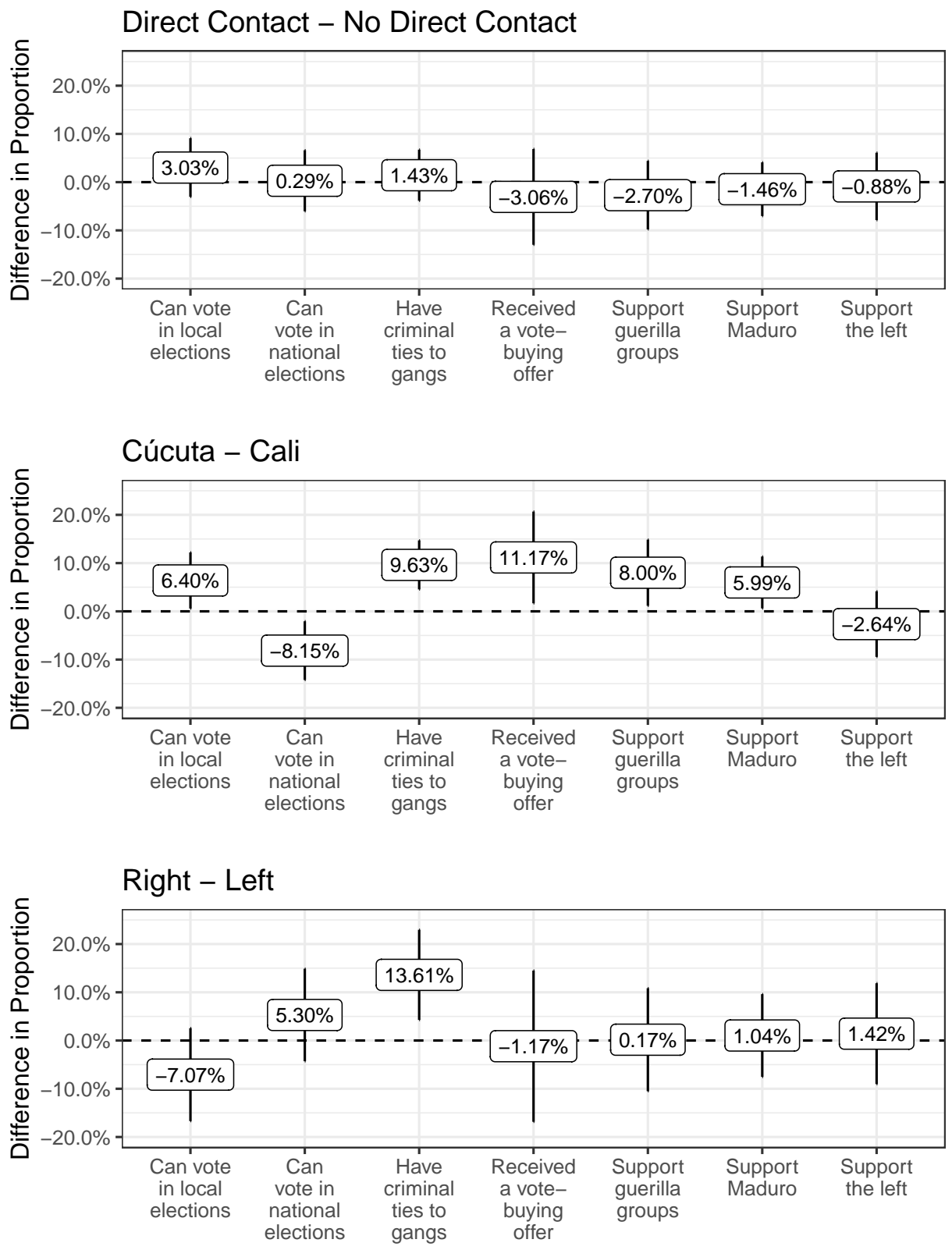

Figure 3: Comparing proportions of misperceptions about Venezuelans by respondent subgroups: whether they have direct contact with Venezuelans (top), whether they live in Cúcuta or Cali (center), and whether their political ideology is right or left (bottom).

It is very difficult to the origins of political misperceptions (Flynn, Nyhan and Reifler, 2017), but we consider three possible channels: contact, strategic electoral adoption, and elite cues. 
We explore these effects through sub-group analyses of our descriptive and experimental data. First, we examine whether political misperceptions stem from limited experience with migrants. If this is the case, then Colombians with no contact with Venezuelans or who live in Cali, where Venezuelan migration is a more recent and limited phenomenon, should be more likely to have misperceptions.

Direct contact is, however, not associated with more accurate perceptions. The first plot in Figure 3 shows the difference in proportion between respondents who have some direct contact with Venezuelans and hold misperceptions across the seven questions, versus respondents with no direct contact. For example, among those who have some (no) direct contact, 31.4\% (28.4\%) believe that the majority of Venezuelan migrants can vote in local elections, for a difference of $3 \%$. But across all questions, the differences between these two groups are not statistically significant. The lack of difference is particularly surprising given the potential for reverse causation in social interactions (i.e., Colombians who hold fewer misperceptions should be more willing to have direct contact with Venezuelans).

Similarly, respondents in Cúcuta should have more accurate views of Venezuelans, given a longer history of cross-border flows and hosting many more Venezuelans, compared to Cali. However, we also do not find the expected differences at the city level. From Figure 3, if anything, a greater proportion of respondents in Cúcuta hold misperceptions about Venezuelans. $32.8 \%$ of our respondents from Cúcuta (26.4\% from Cali) believe they can vote in local elections (although fewer respondents from Cúcuta believe the same for national elections); $60.9 \%$ (49.8\%) believe they receive vote-buying offers; $83.3 \%$ (73.7\%) believe they have ties to criminal groups; $50.3 \%$ (42.3\%) believe they support guerilla groups; and 26.6\% (20.6\%) think that Venezuelans support Maduro. 
Next, we consider whether individuals form misperceptions and care about political affiliations for strategic electoral reasons. First, individuals may use motivated reasoning (Flynn, Nyhan and Reifler, 2017) in making their political assessments. It could be the case that rightleaning individuals are more likely to cast Venezuelans as leftists because they oppose migration. Nevertheless, Colombians on the left and right do not differ in their perception that Venezuelans support the left, can vote, receive vote-buying offers, or support guerrilla groups. The last plot in Figure 3 shows that the only significant difference comes in the perceived likelihood that Venezuelans have ties to street gangs, but this could reflect different base assessments of how prevalent street gangs are in Colombian life.

In contrast, we do find some partisan preference for migrants. If respondents are worried about electoral effects of migrants, partisans should oppose migrants who hold opposing ideological views. The first plot of Figure 4 shows the conditional AMCE based on the respondents' own political ideology. The effect of political ideology is the strongest for those who identify with the political right. Those on the left also seem prefer migrant profiles that support the left but these effects are imprecisely estimated due to the small number of left-leaning respondents. ${ }^{19,20}$

Third, if strategic electoral concerns affect opinions respondents should care about migrants' political affiliations only when they misperceive their electoral incorporation. When individuals believe that migrants can vote, then they should weigh their political ideology more strongly. But against strategic electoral theories, we find no evidence that individuals only care about the ideology of migrants when they inaccurately believe that they can vote in elections. The second plot of Figure 4 conditions on whether the respondent holds the misperception that 19 Venezuelan respondents were also more likely to support migrants who share their political ideology, except for those respondents who identify as left-leaning, who are indifferent.

20 Results are substantively the same with marginal means (SI Section S4). 
Venezuelan migrants can vote in Colombia's national elections or not. While the effects point the right direction (those who hold the misperception prefer right-leaning migrants the most), the differences are not substantively large or statistically distinguishable.

Lastly, if individuals care about immigration for strategic reasons, local electoral geography should matter. Immigrants vary in their "electoral leverage" due to the size and spatial concentration of the migrant population (Dancygier, 2017). Voters may reason that large, concentrated migrant populations could affect election outcomes. If so, fears about migrants' political views should be most acute in communities where migrants compose a larger share of the electorate. In particular, the effect of ideological concerns should be greater in Cúcuta, where Venezuelans make up a much larger and more spatially concentrated share of the population. However, political fears matter equally in Cali and Cúcuta, even though Venezuelan migrants are more likely to swing electoral outcomes in Cúcuta. We therefore find only limited support for strategic electoral explanations.

Finally, we consider whether political elites foster misperceptions. We look for evidence that national politicians spread false information about Venezuelan migrants' political incorporation and that these rumors diffused across the country. ${ }^{21}$ In the context of a polarizing presidential race in 2018, right-wing politicians leveraged fears of a Venezuela-style economic collapse and tried to tie Venezuelan migrants to support for leftist economic policy in Colombia. Faced with a strong challenge on the left - Gustavo Petro, a left-wing former guerrilla fighter and mayor of Bogotá who won $42 \%$ of the vote in the run-off in 2018 and won the presidency in 2022, center and right-wing candidates played up an association between voting for the left and $\overline{21}$ It is difficult to construct subgroups with different exposure to misperceptions given that rumors were ubiquitous and also spread through social media like WhatsApp in addition to traditional media sources. 
By Respondent Ideology

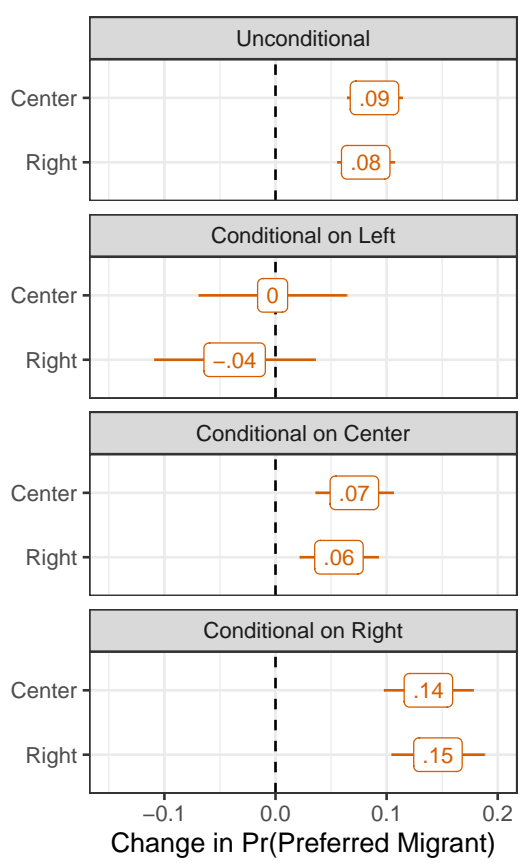

By Respondent Misperception on Venezuelan Access to Vote
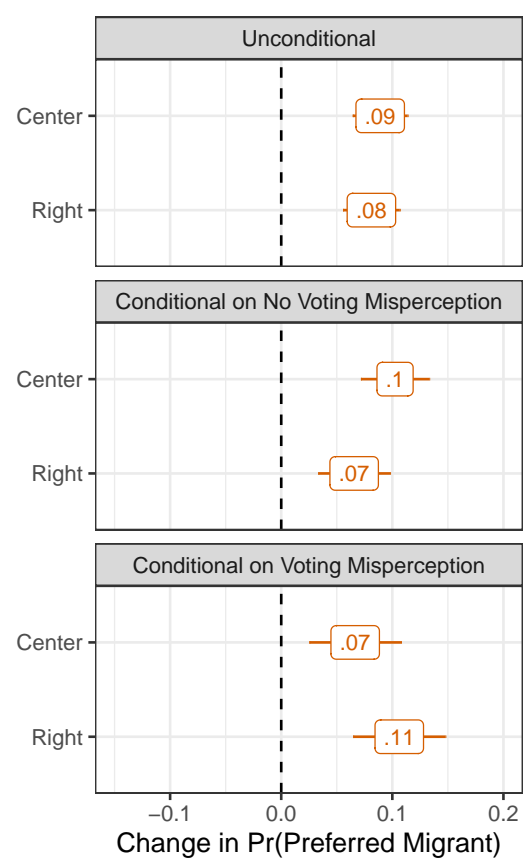

By Respondent City

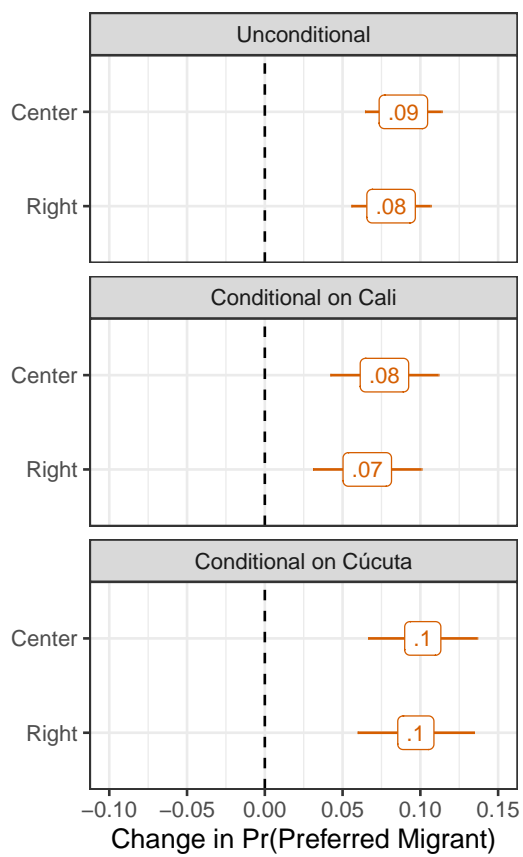

Figure 4: AMCE estimates with 95\% CIs of migrant profile political polarization, conditional on whether they have the misperception that Venezuelans can vote in the national elections (left), and respondents' city (center), and respondents' own political ideology (right).

socialist economic policies. Rumors circulated that Venezuelans could vote in the election. ${ }^{22}$ In particular, former president Álvaro Uribe (2002-10) used his social media presence to scare voters that Venezuelans were bringing left-wing ideas of "castrochavismo," would vote for leftwing parties, and create a "second Venezuela." Uribe tweets constantly and has five million Twitter followers, who may have read his messages directly or spread indirectly through popular WhatsApp chat groups (see SI Section S6 for examples). ${ }^{23}$

Uribe was not alone in linking Petro to socialist ideas. Uribe's ally, President Duque, used the example of Venezuela to portray his opponent as a radical. Propaganda for Duque $22 \quad$ For a discussion, see the fact-checking site, "No es cierto que todos los venezolanos puedan votar en elecciones de Colombia," Colombia Check, May 14, 2019.

23 Right-wing candidates are again using the spector of "castrochavismo" against Petro in the 2022 Presidential Election. www.npr.org/2022/04/28/1094609544/colombia-electioncandidate-gustavo-petro. 
advertised, "The tragedy of Venezuela is the result of a socialist government. Vote wisely, vote Duque" (Ordóñez and Ramírez Arcos, 2019). A leading center-right presidential candidate, Germán Vargas Lleras, also wrote that Colombia risked following Venezuela's economic path: "It's worrying to think that the tragedy in Venezuela can repeat itself in Colombia. I propose to stop it!"24

Rumors spread on social and news media that Venezuelans living in Colombia would swing the election. One widely shared post claimed that the Colombian government expanded Venezuelans' residency permits so they could vote in the presidential elections. ${ }^{25}$ Another viral audio clip featured a supposed Venezuelan leader assuring a Colombian woman, "[Venezuelans] have only come to register as voters, and they are going to support Colombia voting for Petro, for all that is communism." ${ }^{26}$ Right-wing messaging seems to have been effective. One public opinion poll prior to the presidential election found that $55 \%$ of Colombians believed that Venezuelan migrants put the country at risk of becoming another Venezuela (Ordóñez and Ramírez Arcos, 2019). These messages were also repeated by politicians prior to regional and local elections in 2019. For instance, campaign slogans for one of the main right-wing political parties, Centro Democrático, in Bogotá, Bucaramanga, and Cali included, "I don’t want to live like a Venezuelan," and "So Colombia won’t be another Venezuela" (Ordóñez and Ramírez Arcos, 2019).

Accusations about Venezuelans' electoral impact also revolved on their potential role as

24 "Sobre Eln y Venezuela, hay que poner orden ya," El Tiempo, February 18, 2018; www. eltiempo.com/opinion/columnistas/german-vargas-lleras/sobre-eln-yvenezuela-hay-que-poner-orden-ya-german-vargas-lleras-184028

25 "Es falso que están ofreciendo nacionalidad colombiana a los venezolanos para que voten en las elecciones," Colombia Check, July 18, 2019.

26 "Campaña sucia? Cadena de WhatsApp advierte de venezolanos registrados para votar por Presidente," La FM Radio, February 28, 2018, www . lafm.com.co/politica/campanasucia-cadena-de-whatsapp-advierte-de-venezolanos-registrados-para-votarpor-presidente 
a vulnerable, clientelistic base in local elections: rumors circulated that politicians granted Venezuelans identification documents in exchange for campaigning and voting for them. In Cali, the mayor, Maurice Armitage, allegedly distributed ID cards to 11,000 Venezuelans in exchange for participating in the campaign of his ally, Alejandro Éder. ${ }^{27}$

Beyond concerns about a left-wing victory at the polls and the possible policy impacts, right-wing politicians also stressed that Venezuelans threatened Colombia's internal stability. Venezuelan politics has indeed affected the Colombian civil war: evidence from the computer of a captured FARC commander ("Raúl Reyes") suggested that Chávez allowed the FARC to take shelter in and receive arms from Venezuela. Martínez (2017) shows that activity by the FARC increased disproportionately in Colombian municipalities next to the border with Venezuela after Chávez became president. What was new in Uribe's message (and picked up in the media) was that Venezuelan migrants were being recruited to join guerrilla groups; ${ }^{28}$ although, there is little evidence of this happening systematically (Otis, 2019).

In summary, we find little evidence that misperceptions stem from limited contact or strategic adoption by those opposed to migration for other reasons. The results also do not suggest that individuals care about migrants' political views only when they have the potential to change local electoral outcomes. Instead, the findings are most consistent with a theory that political elites cultivate and spread misperceptions (see also Czymara, 2020; Flores, 2018). Extensive media statements and social media messages that Venezuelans favor the left are consistent with widespread misperceptions in cities with more limited and extensive experience with migration. 27 "No, en Cali no están dando cédulas de extranjería a venezolanos a cambio de votos," Colombia Check, December 3, 2018.

28 "Grupos armados colombianos seducen a venezolanos desesperados," Reuters, June 20, 2019; "ELN y ex-FARC mafia reclutan a migrantes de Venezuela por US\$300," Insight Crime, October 16, 2018. 
As we return to in the conclusion, more research linking anti-migrant political media exposure with increased misperceptions about migrants in this context is needed.

\section{Possible Threats to Inference and Generalizability}

While we find robust support for our theory, there are potential threats to inference. First, measuring preferences on surveys raises concerns of social desirability bias. Respondents may stereotype migrants based on their political views to mask racist or economic concerns about their impact. Conjoint experiments help to alleviate this concern because preferences are revealed through pairwise comparisons involving bundles of characteristics, where respondents don't have to justify why they prefer a given profile (Horiuchi, Markovich and Yamamoto, 2021). In this experiment, we do not find evidence of racial discrimination or economic competition concerns.

Second, while conjoint experiments provide high internal validity, one might question their generalizablity and interpretation. This survey took place around local elections where candidates have greater incentives to highlight the political impacts of migration and voters are focused on proximate electoral outcomes. Future research should look at how long these fears persist and the role that political fears play in between electoral cycles. Even if political fears do fade, the results suggest that there may be malleable determinants of public attitudes towards migrants. A related issue is that a forced choice conjoint requires respondents to pick a migrant, whereas "true" preferences may involve accepting no migrants at all. The experiment reveals the relative desirability of migrants but may not be meaningful in a social context where the main electoral demand is to stop or reduce migration. We included a set of descriptive questions to understand Colombians' broader anxieties about Venezuelan migration, which we 
report in SI Section S7, that is also consistent with our first hypothesis that political concerns are dominant.

Third, we sampled urban populations that have received substantial migrants. It is possible that political fears operate differently in rural areas with less direct experience of Venezuelan migration. Rural populations in Colombia, and especially those that have experienced civil war violence, tend to be more politically conservative and many supported former President Uribe during the period under study. The fear of leftist influences from migrants and media exposure to these messages should, if anything, be more acute. Future research on representative national samples may compare urban and rural attitudes towards migrants to test whether political fears differ in salience or motivation.

Finally, while fears of the left may seem uniquely important in Colombia due to its history of internal conflict and leftist guerrillas, politicians have reasons to stoke political fears of migrants to discredit their opponents in a broad set of circumstances. Across Latin America, right-wing politicians try to scare voters away from moderate left parties by emphasizing their proximity to communist or socialist ideologies. For instance, Brazilian President Jair Bolsonaro alleged that his opponent from the Workers Party (PT), Fernando Haddad, would lead Brazil down the same socialist path as Venezuela and initially encouraged the deportation of Venezuelan migrants to "stop Brazil becoming a Cuba or a Venezuela." ${ }^{29}$ In Peru, presidential hopeful Keiko Fujimori warned of communist infiltration by Venezuelans to turn voters against her left-wing competitor, Pedro Castillo. Beyond Latin America, this tactic is thought to have swayed Cuban and Venezuelan voters in the US to turn to the Republican Party to avoid potential "socialism" 29 See for example: www.theguardian.com/world/2018/oct/11/brazil-venezuela-jairbolsonaro-workers-party 
promoted by the Democratic Party. ${ }^{30}$ Our findings likely carry to other countries still shaped by post-Cold War cleavages and wary of the extreme political ideologies that migrants tend to flee.

\section{Conclusion}

In much of the Global North, differences in ethnic, racial, or religious backgrounds overlap with perceived differences in political views. In this paper, we studied a context in which migrants often are indistinguishable in demographics but come from a country that followed a divergent political trajectory. In a context of demographic similarity, we showed how Colombian politicians, media outlets, and citizens constructed an out-group based on Venezuelans' political leanings. Right-wing politicians, in particular, have underscored a socialist threat coming from Venezuelan migrants. This paper provides evidence that these elite messages resonated among local communities, and that host communities worry about the electoral impacts of migration.

We use original survey data to show a substantial gap between Colombians' perceptions and Venezuelan migrants' reported political views. While Venezuelan respondents were more right-wing than Colombians, many Colombians perceived them as left-wing and vulnerable to recruitment by clientelist parties or armed groups. In a conjoint experiment, both Colombians and Venezuelans showed a strong bias against left-leaning migrants. Interestingly, we find little evidence that race or ethnicity shaped migrant reception. In the Global North, race and ethnic differences dominate the discussion of immigration policy. As in other studies of the Global South (Alrababa'h et al., 2019), race and ethnicity play a secondary role. Though our broader survey showed that Colombians had many concerns about Venezuelan migration, and

30 See for example: www.npr.org/2015/12/17/460149169/undocumented-democrats-isted-cruzs-new-politically-correct-term 
xenophobia is on the rise, it is not rooted in racial or ethnic concerns, but largely political ones.

Our findings suggest that the political consequences of migration are likely to be the opposite of those feared by host countries. As Venezuelans gain the right to vote, they are likely to push the electorate further right. Indeed, consistent with our findings, one study of municipal election results shows an increase in support for the political right where Venezuelan migration has increased the most (Rozo and Vargas, 2021). Yet the channel of electoral impact differs. Rather than simply an increase in xenophobic appeals, we show that voters may turn to the political right out of fear of following a similar leftist path like Venezuela, and eventually migrants that sympathize with the right will gain the right to vote in local elections. Our results also reinforce the potential impact that emigration has on politics in Venezuela: even those fleeing for economic reasons are deeply dissatisfied with Maduro. Migrants may have strengthened the political opposition to the regime had they stayed.

Given the gap between perceived and actual political views, our results suggest a potential role for the media to strengthen support for migrants and for future research on how political parties design their migration platforms. Rumors circulating through social media that Venezuelans support socialist policies, already are voting in large numbers, and are bought off by clientelistic politicians or recruited by armed groups can create antipathy among Colombians, particularly among right-leaning Colombians. Campaigns providing accurate information about whether migrants can participate in elections and Venezuelans' critiques of their government's policies potentially could help build support for their resettlement. Important research remains to be done on how host communities learn about migrants' political views, and whether media and political campaigns can correct misperceptions.

Finally, this paper suggests an interesting tension for leaders of conservative political par- 
ties. While the political right often is associated with anti-immigrant messages, immigrants may become an important bastion of its political support in contexts where they flee left-wing regimes. How right-wing parties campaign to attract anti-immigrant voters, and court migrant votes is an interesting dilemma. Whether migrants are portrayed as "unskilled," "culturally backwards," "leftist" or "terrorists" depends on the existing political context and how parties sow divisions to boost their own electoral prospects. 


\section{References}

Adida, Claire L. 2014. Immigrant exclusion and insecurity in Africa. Cambridge University Press.

Alarian, Hannah. 2021. "Local Suffrage increases Citizenship Acquisition: Evidence from the European Union.”. Working Paper.

Alrababa'h, Ala', Andrea Dillon, Scott Williamson, Jens Hainmueller, Dominik Hangartner and Jeremy Weinstein. 2019. "Attitudes toward migrants in a highly impacted economy: evidence from the Syrian refugee crisis in Jordan." Comparative Political Studies p. 0010414020919910.

Bansak, Kirk, Jens Hainmueller and Dominik Hangartner. 2016. "How economic, humanitarian, and religious concerns shape European attitudes toward asylum seekers." Science 354(6309):217-222.

Bhavnani, Rikhil R and Bethany Lacina. 2018. Nativism and Economic Integration Across the Developing World: Collision and Accommodation. Cambridge University Press.

Cogley, Nathaniel Terence, John Andrew Doces and Beth Elise Whitaker. 2018. "Which Immigrants Should Be Naturalized? Which Should Be Deported? Evidence from a Survey Experiment in Côte d'Ivoire." Political Research Quarterly p. 1065912918801104.

Czymara, Christian S. 2020. "Propagated preferences? Political elite discourses and Europeans openness toward Muslim immigrants." International Migration Review 54(4):1212-1237.

Dancygier, Rafaela M. 2017. Dilemmas of inclusion: Muslims in European politics. Princeton University Press.

Escobar, Cristina. 2017. Migration and franchise expansion in Latin America. Technical report.

Ferris, Dan, Ron Hayduk, Alyscia Richards, Emma Strauss Schubert and Mary Acri. 2019.

"Noncitizen Voting Rights in the Global Era: A Literature Review and Analysis." Journal of International Migration and Integration pp. 1-23.

Flood, E Thadeus. 1977. "The Vietnamese refugees in Thailand: Minority manipulation in counterinsurgency." Bulletin of Concerned Asian Scholars 9(3):31-47.

Flores, René D. 2018. "Can elites shape public attitudes toward immigrants?: Evidence from the 2016 US presidential election." Social Forces 96(4):1649-1690.

Flynn, DJ, Brendan Nyhan and Jason Reifler. 2017. "The nature and origins of misperceptions: Understanding false and unsupported beliefs about politics." Political Psychology 38:127-150.

Gaikwad, Nikhar and Gareth Nellis. 2017. "The Majority-Minority Divide in Attitudes toward Internal Migration: Evidence from Mumbai." American Journal of Political Science 61(2):456472.

Goldstein, Judith L and Margaret E Peters. 2014. "Nativism or economic threat: Attitudes toward immigrants during the great recession." International Interactions 40(3):376-401. 
Hainmueller, Jens and Daniel J Hopkins. 2014. "Public attitudes toward immigration." Annual Review of Political Science 17.

Hainmueller, Jens and Daniel J Hopkins. 2015. "The hidden American immigration consensus: A conjoint analysis of attitudes toward immigrants." American Journal of Political Science $59(3): 529-548$.

Hainmueller, Jens, Daniel J Hopkins and Teppei Yamamoto. 2014. "Causal inference in conjoint analysis: Understanding multidimensional choices via stated preference experiments." Political Analysis 22(1):1-30.

Hanson, Gordon H, Kenneth Scheve and Matthew J Slaughter. 2007. "Public finance and individual preferences over globalization strategies." Economics \&f Politics 19(1):1-33.

Hiskey, Jonathan T, Abby Córdova, Mary Fran Malone and Diana M Orcés. 2018. "Leaving the devil you know: Crime victimization, US deterrence policy, and the emigration decision in Central America." Latin American Research Review 53(3):429.

Hopkins, Daniel J, John Sides and Jack Citrin. 2019. "The muted consequences of correct information about immigration." The Journal of Politics 81(1):315-320.

Horiuchi, Yusaku, Zachary D Markovich and Teppei Yamamoto. 2021. "Does conjoint analysis mitigate social desirability bias?" Political Analysis .

IOM. 2018. Migration Trends in the Americas. Technical report.

Janetsky, Megan. 2019. "Here's Why Colombia Opened Its Arms to Venezuelan Migrants Until Now." Foreign Policy . https://foreignpolicy.com/2019/01/14/heres-why-colombiaopened-its-arms-to-venezuelan-migrants-until-now/.

Lim, Junghyun. 2022. "The Electoral Consequences of International Migration in Sending Countries: Evidence from Central and Eastern Europe." Comparative Political Studies .

Martínez, Luis R. 2017. "Transnational Insurgents: Evidence from Colombia's FARC at the border with Chávez's Venezuela." Journal of Development Economics 126:138-153.

Mayda, Anna Maria. 2006. "Who is against immigration? A cross-country investigation of individual attitudes toward immigrants." The review of Economics and Statistics 88(3):510530.

Miller, Michael K and Margaret E Peters. 2020. "Restraining the huddled masses: Migration policy and autocratic survival." British Journal of Political Science 50(2):403-433.

Ordóñez, Juan Thomas and Hugo Eduardo Ramírez Arcos. 2019. "(Des)orden nacional: la construcción de la migración venezolana como una amenaza de salud y seguridad pública en Colombia." Revista Ciencias de la Salud 17:48-68.

Otis, John. 2019. "Fleeing Crisis, Some Venezuelans Are Recruited By Rebel Forces Fighting In Colombia." NPR Weekend Edition Sunday. https://www.npr.org/2019/01/ 18/685850399/fleeing-crisis-some-venezuelans-are-recruited-by-rebel-forcesfighting-in-colomb. 
Pérez, Efrén O. 2015. "Ricochet: How elite discourse politicizes racial and ethnic identities." Political Behavior 37(1):155-180.

Posner, Daniel N. 2005. Institutions and ethnic politics in Africa. Cambridge University Press.

Radnitz, Scott and Harris Mylonas. 2022. Theorizing Fifth-Column Politics. In Enemies Within: the Global Politics of Fifth Columns. Oxford University Press.

Rettberga, Jill Walker and Radhika Gajjalab. 2015. "Terrorists or cowards: negative portrayals of male Syrian refugees in social media." Feminist Media Studies 16(1):178-181.

Richard, Sisk. 2016. "ISIS Fighters Hiding Amongst Refugees Pose Terror Threat: Breedlove." Military.com .

URL: https://www.military.com/daily-news/2016/03/01/isis-fighters-hiding-refugees-postterror-threat-breedlove.html

Rozo, Sandra V and Juan F Vargas. 2021. "Brothers or invaders? How crisis-driven migrants shape voting behavior." Journal of Development Economics p. 102636.

Simpser, Alberto. 2020. "The Culture of Corruption across Generations: An Empirical Study of Bribery Attitudes and Behavior." Journal of Politics .

Steele, Abbey. 2017. Democracy and displacement in Colombia's civil war. Cornell University Press.

Thachil, Tariq. 2017. "Do rural migrants divide ethnically in the city? Evidence from an ethnographic experiment in India." American Journal of Political Science 61(4):908-926.

Whitaker, Beth Elise and Jason Giersch. 2021. "Strategic calculations? Partisan differences in support for Puerto Rican migration to the mainland USA." Migration Studies .

Woldemikael, Olivia. 2022. "The Impacts of Venezuelan Migrant Transit Routes in Colombia.". 